\title{
Effects of Corruption on Managers Communication and Networking Behaviours: Implications for Nigeria and Ghanaian Public Sector Effectiveness
}

\author{
Ethelbert Chinedu Nwokorie* \\ School of Management, Public Management, University of Vaasa, P.O. Box 700 (Wolfintie 34), 65101 Vaasa, \\ Finland
}

*Corresponding Author: Ethelbert Chinedu Nwokorie, School of Management, Public Management, University of Vaasa, P.O. Box 700 (Wolfintie 34), 65101 Vaasa, Finland

\begin{abstract}
This article examines how corruption influences public managers' communication and networking behaviours, and the challenges such behaviours creates that undermine the effectiveness of public sector organizations. It analyzes how the challenges manifest in communication and networking behaviours of public managers. This qualitative study compares public sector managers in Nigeria and Ghana. Empirical data were collected through semi-structured interviews with managers of some public sector organizations in the two countries. Findings reveal that corrupt values in these societies influence the official behaviours of public sector managers while performing communication and networking functions. Due to corruption, networking functions make public sector managers vulnerable to unethical behaviours. Corruption creates high power distance value system in these societies. Public managers like other members of the society crave for high social. As a result, they manifest bossy behaviours and create status barriers in order to draw subordinates attention and respect to their positions. This limits horizontal communication between managers and subordinates.
\end{abstract}

Keywords: Corruption, Effectiveness, Public Managers, Communication and Networking Behaviours.

\section{INTRODUCTION}

Management behaviour is an important factor in building an effective organizational team and employee motivation. The ability of managers to perform their functions effectively is the key to goal actualization (Walela \& Okwemba 2015: 239). Previous studies have established the relationship between official behaviours of managers', employees' performance and organizational goal actualization (Walela \& Okwemba 2015: 240; Danişman, Tosuntaş \& Karadağ 2015: 144; Loke 2001: 192). Effective management is defined based on goal actualization. However, since organizational goals vary, effectiveness varies according organizations and their goals (Nwokorie 2017: 14). Effectiveness is perceived as the common goal of modern management, although different people in different situations define the concept differently (Luthans, Welsh \& Taylor 1988: 148).

Organizations depend on the performance of management to succeed in actualizing their goals. How well managers manage determines whether organizations achieve their goals or not (Drucker 2011: 4). How managers perform management functions affects employees' productivity and organizational effectiveness (Nwokorie 2017: 91). According to Luthans, Hodgetts and Rosencrantz (1988: 62), "effective managers", those who achieve the goals of their organizations with committed subordinates do not necessarily succeed in getting quick promotions. Instead, "career successful" managers who use their positions to network for their career success are the ones that get rapid promotions. Corruption negatively affects managers' communication and networking behaviours. Due to corruption, public managers are more involved in networking activities for their individual benefits than to achieve organizational goals. Management activities like recruitment, promotion, rewards and appointments in public sector organizations often depend on "who you know"; while merit, qualification, performance and competence do not practically count much during these management activities in public sector organizations in Nigeria (Nwokorie 2017).

This study seeks to examine how behaviours of Nigeria and Ghanaian public sector managers pose challenges that undermine effectiveness of public sector organizations while performing 
communication and networking functions. As leaders, managers' behaviours should encourage and motivate subordinates to achieve organizational goals (Tweedy 2014: 49). However, only few studies have examined the quality of managers' behaviours and its impact on organizational performance (Yukl 2012: 75).

\section{MethodologY}

This qualitative research is a comparative study conducted by interviewing senior and middle level managers of some public sector organizations in Nigeria and Ghana, using semi-structured interview technique as the method of empirical data collection. Denzin and Lincoln (2005: 3) and Hennink, Inge \& Ajay (2011) view qualitative research as a positioned activity that puts the observer in the research context in order to get a proper understanding of the phenomenon under study. The process includes some activities and practices like field notes, interviews, conversations, photographs, recordings, observations, etc. through which the phenomenon is revealed. They make qualitative researchers carry out their studies in real situations, and interpret the phenomena according to the meanings people give them. In this study, qualitative method has provides excellent opportunity to understand ineffectiveness of public sector organizations in Nigeria and Ghana.

Earlier prepared interview guide shaped the interview questions. Thirty-seven face-to-face interviews were conducted with managers in twenty-one selected public sector organizations in Nigeria and Ghana between 14th of May 2014 and 27th of March 2015. Minimum of two people were interviewed separately in each organization. Group interviews were conducted in three organizations in Nigeria where managers requested for group interviews. Interview questions were framed to link each other, so that relevant information missing in response to previous questions could surface in the response to subsequent questions. Organizations were selected for interviews based on the following classification of public sector organizations in the two countries: government ministries, extra/non-ministerial departments, government agencies and parastatals, government corporations and enterprises, government institutions and local governments.

The interview questions were designed according to the typology of managers' networking and communication activities developed by Luthans et al. (1988). They sought to identify the challenges managers' networking and communication activities pose to effective management of organizations, and how those challenges manifest in behaviours of managers'. Luthans et al. typology was chosen because the behaviours of the managers they observed were similar to the behaviours of public managers in these countries. Framework analysis approach was used for the interview analysis. This involved reading the interview transcript many times, developing and assigning codes based on the theme. Data were assigned to the themes in the codes manually. The coded data were refined by summarizing and synthesizing the initial themes to identify patterns between the themes, and to ensure a well presentation of interviewees' account. Framework as a systematic approach to data analysis is used to organize and manage research through summarization. This results in a robust and flexible matrix that allows the researcher to analyze data by case and theme (Edhlund \& McDougall 2016: 239).

\section{REVIEW OF RELATED LiTERATURE}

This study uses the typology of managers networking and communication behaviours and activities developed by Luthans, Hodgetts \& Rosencrantz (1988) as a framework to examine the impact of managers' networking and communication behaviours on the effectiveness of public sector organizations in corrupt societies. This framework is chosen because it provides some explanation on the relationship between managers' behaviours and ineffectiveness in corrupt societies (Nwokorie 2017: 21). Networking was observed in Luthans et al. (1988: 119) study as behaviours of managers which include socializing and politicking, networking-related chit chats, informal joking around, discussing rumours, complaining, griping, downgrading others, and gamesmanship. It includes interacting with "outsiders" including customers, external meetings, and community services. Networking represents informal organization, it employs sociopolitical skills and connections; it develops contacts and reciprocal networks to increase available resources. While the observed communication activities include exchanging routine information and paper work. O'Driscoll, Humphries and Larsen (1991: 313) are of the view that the typology of managerial activities and behaviours developed by Luthans et al. provides a better framework for understanding managerial 
Effects of Corruption on Managers Communication and Networking Behaviours: Implications for Nigeria and Ghanaian Public Sector Effectiveness

roles and activities, because it provides a specific classification based on observations of actual behaviours in each activity.

Luthans et al. (1988) study reveals that networking has stronger relationship with managers' success and weakest relationship with organizations effectiveness; while communication shows stronger contribution to effectiveness, followed by human resource management. The study further observed that "successful" managers do not perform equal amount of the same functions as effective managers do (Luthans et al. 1988: 66-69). Effective managers perform more communication and human resource management functions; while managers who focus on networking functions are not utilizing their full potentials for effective management (Luthans et al 1988: 171). Although the study was silent on corruption, corrupt values negatively influence the behaviours of public sector managers. This makes them act in ways that diminish ethical standards and poses challenges to effectiveness of public sector organizations (Nwokorie 2017: 95).

Luthans et al. (1988) study of managerial activities and behaviours has attracted the attention of some researchers who sought to verify the findings and the relationship between managerial activities/behaviours and organizational effectiveness/ineffectiveness. Findings by previous studies on the effects of managers' behaviours on organizational effectiveness demonstrate consistent correlation between behaviours of managers and employees' effectiveness/ineffectiveness. Researches have shown that employees' perception of managers' behaviours affect their job satisfaction, productivity, commitment and organizational effectiveness positively or negatively (Walela \& Okwemba 2015: 240; Danişman, Tosuntaş \& Karadağ 2015: 144; Loke 2001: 192). According to Pepermans, Mentens, Goedee, Jegers and Van Roy (2001: 283), some researchers suggest that Luthans et al. typology provides a better framework for understanding managerial activities and roles. Van Der Velge, Jansen and Vinkenburg (1999: 172) agree that Luthans et al. (1988) typology of managerial activities is a good encapsulation of the entire entity of management and its functions. O'Driscoll, Humphries and Larsen (1991: 313-326) sought to compare managers and subordinates ratings of managerial performance on the set of activities developed by Luthans et al. (1988) study. They sought to examine the contributions of specific managerial functions to effectiveness by using Luthans et al. (1988) classification of managerial activities. The studies aimed to determine if certain types of managerial role(s) contribute more to effectiveness. The findings were consistent with the conclusions of Luthans et al. (1988) studies, that communication and human resource management functions have substantial correlation to effectiveness. It also confirms Luthans et al. (1988) findings that managers' communication behaviours affect effectiveness.

Pepermans, Mentens, Goedee, Jegers and Van Roy (2001: 293), adopted Luthans et al. typology of managerial activities and behaviours in an observational study aimed to determine if there are differences between managerial behaviours of European Intensive Care Unit (ICU) head nurses and ICU medical directors, in order to come up with a managerial job and competency analysis of ICU managers. Their study reveals that communication activities were more important in ICU management, while their observational data showed that networking activities were of less importance. In another study aimed at identifying the effects of managerial activities on managers' success and effectiveness, using Luthans et al. (1988) typology, Chung-Ming, Ng and Mee-kau (1997: 433-445) embarked on a three country study of Canadian, Hong Kong and Taiwanese managers. The result of their study corroborated Luthans et al. (1988: 160) findings, that "effective" and "career successful" managers do not perform equal amount of the same functions. According to their findings, in Hong Kong, human resource management activities contribute positively to effectiveness. The research further reveals that effective managers' in all these countries are not recognized, nor rewarded. This also corroborates Luthans et al. (1988) finding on human resource management function, which came second after communication. Also, it agrees that effective managers often lose their rightful rewards to "career successful" managers who use networking activities to advance their career progression. Srivastava and Nair (2011: 303-314), used a different model from Luthans et al. (1988) typology in their study on the effects of managers behaviours on organizational effectiveness. Their findings on the study of effects of androgynous and rational-emotive behaviours to effectiveness supported the findings of Luthans et al. (1988) that the behaviours managers' exhibit while performing their managerial activities positively or negatively affects organizational effectiveness.

Friar and Eddleston (2007: 104-127) study on the value of networking confirms Luthans et al. (1988) findings on managers' networking activities. The study corroborates Luthans et al. (1988: 42) 
conclusion on the relationship between networking and managers' success. The study agrees that networking leads to managers' career success than organizational effectiveness. Findings on figurehead roles of managers in Mintzberg (1980: 58-59) study is similar to Luthans et al. (1988: 119) findings on managers networking functions. Mintzberg's study reveals that figurehead roles of managers are not significant in decision-making and information processing. Managers share information, maintain good communication and contact with employees and stakeholders when performing the leader, informational, liaison, negotiator, disseminator and spokesman roles, Mintzberg (1980: 63-64, 75-76). These communication activities are necessary for information processing and decision-making, which significantly contributes to effectiveness. Furthermore, in a study to determine both the frequency and the importance of managerial activities performed by top and middle level managers of a large insurance company in the Netherlands, Van Der Velge, Jansen and Vinkenburg (1999: 169) corroborates Luthans et al. (1988) finding that career successful managers are more involved in networking functions than communication functions.

In a comparative study aimed at re-examining the findings of Luthans et al. (1988) study on successful and effective managers, Chalmers (1991: 58-59) compared the issue of successful and effective management styles within New Zealand and American contexts. The result of the study reestablished the findings of Luthans et al. (1988) on successful and effective managers. Among other findings, the study reveals that subordinates of most successful (career successful) managers confirmed that they do not get proper information about their work and do not have a clear knowledge of their units' goals. The result further show that they were not committed, and never found their managers to be effective. Successful managers surveyed in the study spent much of their time on networking activities, while disregarding communication activities. However, like in Luthans et al. (1988) study, effective managers are the ones that produce committed, loyal and highly productive employees. According to Robbins (2009: 6-7), several studies conducted in different countries have confirmed that networking is the medium for managers' career success. These studies help to establish the link between networking and managers career success. It shows that managers who engage more in networking functions tend to focus more on achieving their personal goals that the organizational goals; which affects organizational effectiveness. Based on these, Luthans et al. (1988) typology of managerial activities provides a useful background to study the effects of managers' communication and networking behaviours on organizational effectiveness in corrupt societies.

\section{Communication ACTIVITY}

Communication is the medium through which management activities are coordinated. Good communication is an important instrument for successful management. Management functions depend on effective communication to succeed (Zelter 2011: 69). Regular communication between managers' and employees help to increase employees' satisfaction and organizational effectiveness (Christiansen \& Chandan 2017: 202; Lashley \& Lee-Ross 2003: 801). Luthans et al. (1988: 68) observational study of managers discovered that effective managers engage more in communication activities, and communication activities show high relative contribution to manager's effectiveness. Effective communication between managers and employees' unlocks organization's key to success (Young \& Post 1993: 31-32). Mintzberg (1980) in his observational study of managers highlighted the importance of communication in management. He identified ten roles of managers, which he classified into three: (i) interpersonal roles: figurehead, leader and liaison; (ii) informational roles: monitor, disseminator and spokesman; (iii) decisional roles: entrepreneur, disturbance handler, resource allocator and negotiator. Communication is central to managers' success in the three roles because communication is the medium through which managers functioned in each of the observed roles (Mullins 2007: 424). Effective communication help managers to build positive relationship, establish good networks and strengthen their leadership roles within their organizations, increase trust, cohesion, motivation, understanding and upward/downward information movement. These in turn increase employees' productivity. However, face-to-face communication provides public managers and employees the opportunity to understand each other's unspoken body language (Zelter 2011: 69; Grunig, Grunig \& Dozier 2002; Grunig 1992: 12; Picardi 2001: 5, 10; Chaturvedi \& Chaturvedi 2006: 43).

Through face-to-face communication, managers exchange routine information with employees', answer procedural questions, disseminate requested information, convey results of meetings, give out 
and receive information. These make face-to-face communications more effective than routine functions of handling paperwork, processing mails, memos and general deskwork, which are still communication functions (Grunig 1992: 12; Luthans et al. 1988: 96). Picardi (2001: 5, 10) explains that email and text messages that have predominantly become a sort of communication by todays managers are not communication; they are channels for message delivery. Real communication happens through face-to-face information delivery, because it carries along with it the power of verbal and body languages to convince and persuade employees, and clarify issue almost instantly. Unlike written communication that lacks the possibility of providing spontaneous feedback. Face-to-face communication carries greater proportion of the quantity of transmitted messages, about seventy percent of communication which includes gestures, mimics, tone of the voice or punctuality happen during face-to-face communication (Zelter 2011: 69). It helps managers to keep track of their employees' and every development in work place. Young and Post (1993: 38) noted that no other communication media could be better than face-to-face communication, when communication involves human side of organizational changes. Effective listening, downward, upward and horizontal communication increases feedback opportunity. This leads to effective performance, strengthens managers' leadership and influence over subordinates. In corrupt societies, corruption leads to status barrier which inhibits flow of communication if unchecked by managers. It creates environment where people get respect and recognition because of their position, instead of quality of their inputs (Mosley Jr., Mosley Sr. \& Pietri 2011: 178). Effective face-to-face communication is important for management effectiveness (Robbins 2009: 282).

\section{NETWORKING ACTIVITY}

Managerial networking is a process through which managers interact with others and external actors within and outside their organizations in form of exchange relationships. It is "a set of games" (cf. Meier \& O'Toole Jr. 2010c: 137). Networking has become an important tool in today's management. Much of the works expected of managers are beyond their individual capabilities. They need the support and contributions of other people to make the difference between success and failure. Through networking, managers develop the capacity to attract support and help from colleagues and others to get things done (Schermerhorn 2011: 14). Individuals and organizations network for personal and organizational purposes, sharing information, matching services, and solving policy problems. The increasing need and importance of networking has made it an integral part of public managers' job. This reveals the importance of collaborative management for managers (Agranoff 2007: 2-4). Through networking, managers attract financial resources to their organizations from both government and financial institutions (Su, Xie \& Wang 2015: 228-248).

Meier and O'Toole Jr. (2010a: 1025) however argue that evidence from some studies have prove wrong the claims on the positive effects of networking. According to them, networking only affects positively on managerial performance where there is management capacity. By management capacity, they mean a central unit that sets targets for managerial network and evaluates managers' performance in network management. Networking between public managers and political principals negatively affect managers' effective performance (Meier \& O'Toole Jr. 2010a: 1025-1044). Hence, networking can be of positive and negative effects to managerial performance. Managers who use networking for career success are different from effective managers. Effective managers maintain high employee morale, and high performance standard in achieving organizational goals. Managers who network for career success build alliances and seek to obtain positions of power. Managers networking for promotion, use networking as the medium to influence the superiors who are in a position to influence their promotion (Huczynski 2004: 307). Power is an important factor for networking for career success; managers who network for personal benefits are very power conscious (Luthans et al. 1988: 124-125). Interestingly, power distance index classification show that Nigeria, Ghana among other West African countries have high power distance value, with power index score of 77 (Hofstede, Hofstede \& Minkov 2010: 57). This could explain why managers in the two countries seek to acquire and make use of power (Gudykunst \& Carmen 2003: 20). This situation fuels intrigue among public sector managers.

Parkin (1996: 10) argues that networking is a mere image laundering where managers commit much effort in pleasing their superiors. Survival and success of such managers' depend on how much their superiors love them. They struggle to give impression of good team members, gain credit and build 
alliances. Luthans et al. (1988: 120) and Berryman-Fink and Fink (1996: 185) define network in relation to its prospect for managers' career success. The primary goal of networking managers according to them is career progression. However, some studies including Meier and O'Toole Jr. (2010c) show that even though networking is an important part of modern management functions, it leads to ineffectiveness when it is used to achieve personal ends. Luthans et al. (1988 128-129) claim that mentoring, an aspect of networking is beneficial to the organization. Through mentoring, a powerful manager sponsors protégé (subordinate), who gets psychological and social support, confidence, assistance, access to resources and protection. While in return, the mentor gets information, loyal followers, associates, and an expansion of her/his power base from the protégé and the followers. This is a form of motivation to the protégé and the followers to make them put in their best for their success and to some extent, the success of the organization, since they have the support of the manager (Riggio 2016: 383). It is an example of how negative networking operates, since the mentor and the protégé are not acting in the sole interest of the organization, but for the actualization of their individual interests.

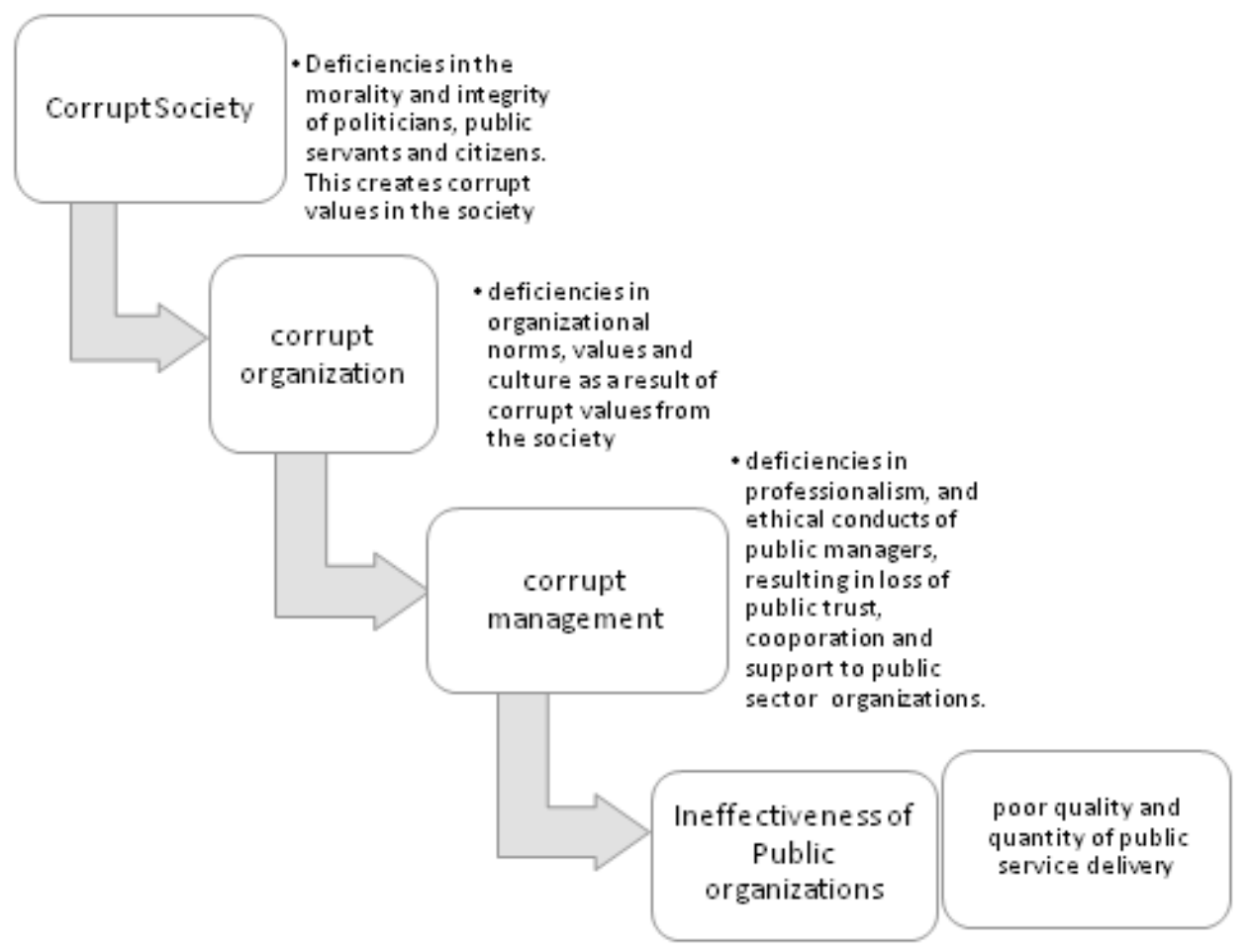

Figure1. How corruption affects managers' behaviours and organizational effectiveness (Nwokorie 2017).

\section{Managers Networking Behaviour and Organizational EFFECTIVEnESS}

Through networking, managers build strong and valuable contacts within and outside their organizations. These contacts protect them and pave ways for their quick promotions ahead of their colleagues. In Nigeria, more than half of the interviewees agreed that their position as managers offer them opportunities to advance their career prospects. Similarly, in Ghana all the interviewees held the same view. They consider managerial positions as a springboard to achieve career success. Having got to the position of a manager, they get more involved in what will make their superiors and people outside the organizations like them and influence their promotions ahead of others. The quests for career progress make public managers to engage more in networking functions than communication activities. This makes them deviate from the organizational goals.

During networking, interactions between public managers and people from outside their organizations directly or indirectly influence managers' official behaviours which expose them to unethical behaviours. This subsequently affects their effectiveness. However, nearly all the interviewees revealed that their interactions with people from outside their organizations influence them positively because the contributions, advise and criticisms they get from the people during their networking function help them to gain more knowledge, evaluate their performance, make corrections where necessary and improve on their performance. But, few interviewees from Nigeria were of the view 
Effects of Corruption on Managers Communication and Networking Behaviours: Implications for Nigeria and Ghanaian Public Sector Effectiveness

that their interactions with people from outside their organizations influence them negatively because people from outside their organizations exert much pressure on them to involve in corrupt behaviours. Public managers' interactions with people outside their organizations provide opportunities for people to influence them positively or negatively.

"Usually, people come from various spheres of the society; they come with their own ideas. In some cases, you discover that they may have some ideas, which are better than what you had before but after discussing and interacting with them, you discover that their own ideas are superior to my ideas and which I always learn from such situation".

"When you talk about accountability, integrity and morality, people look at you like you come from the sky. People try to bribe you in the course of your job... They think you should be corrupt and make more money, and they ask if you alone can sanitize this country and this affects us negatively in delivering our mandate here".

Political influence on public managers is one of the factors that influence managers' official behaviour in Nigeria and Ghana. Politicians allocate resources to, and head most public sector organizations in these countries. As part of public managers' jobs, they maintain close contacts with the politicians. Hence, it is difficult to avoid political influence, which affects networking behaviours and activities of public sector managers. Interviews from the two countries reveal that managers experience negative political influence and interferences during networking functions.

According to them, politicians interfere and influence management activities like recruitments and promotions, posting and transfer of employees, by pressurizing public managers to recruit, promote or transfer their candidates to better positions in their organizations. Other ways include tampering with budgetary allocations of public sector organizations, etc. This negatively influence the official behaviours of public managers who do not want to offend the politicians in order to keep their jobs; strengthen their positions in their organizations, get assurances of speedy promotions and more resource allocation to their organizations. Such behaviour affects the effectiveness of public sector organizations in these societies because merit and competence no longer matter; public managers no longer work to achieve organizational goals, rather to satisfy their political masters and their personal goals.

"So many things have influence over the management of the Nigerian society... People sometimes come with letters from highly positioned people in the society and merit is not considered. Sometimes, when these highly placed people in the society come soliciting for one thing or the other, you have to wave so many things to appeal to them..., and if you do not do that, you will not succeed..."

"Yes, we get plenty of them. Political office holders often talk about their constituency and they do not support anything that does not favour them. For example, during budget defense, we have cases of them asking how many people you will give them, in terms of employment of those from their constituency. If you don't, they obstruct your presentation and distort the budget".

In these situations, public managers have no choice than to 'cooperate'. In some cases, refusal could lead to transfer, removal of such manager, or her/his organization will be starved of funds. These make public managers to collaborate with greedy politicians to carryout acts of corruption in public organizations. It makes the public to lose trust and confidence in public managers and public organizations. With such negative perception, it becomes difficult for the people to believe in public managers, or cooperate with public organizations for successful implementation of government programmes and policies.

Corruption diminishes the value system of a society. Those who corruptly enriched themselves are given high social value, recognition and respect due to their ill-gotten wealth. This leads to inordinate struggle among citizens to acquire wealth, which accords them high social value, respect and recognition. As members of the society, public managers also desire social value, respect and recognition that come through legitimate or illegitimate wealth. Such desire influences the networking behaviour of public managers in the two countries. Due to their positions in their organizations, members of the society believe that they have access to public funds; as a result, the people respect 
Effects of Corruption on Managers Communication and Networking Behaviours: Implications for Nigeria and Ghanaian Public Sector Effectiveness

and give lots of honor and privileges to them. In return, the people expect them to reciprocate the honor, respect and privileges accorded to them. The situation puts pressure on public managers. Due to the pressure and desire to maintain the high status they enjoy in the society, some public managers compromise ethical standards and steal public funds to reciprocate the respect and privileges they enjoy. Such unethical behaviour affects effectiveness of public organizations in these countries.

"Competition for wealth within the environment affects behavior of managers in this organization because sometimes, managers are pushed to behave inappropriately. This reduces the level of revenue mobilization in this organization".

"...In a society where wealth and bogus status is accepted as a norm, heads of government agencies are bound to be negatively influenced and if they don't dance to the tune, their status will be demeaned. For those young officers, all the talks about public service ethics and values are nowhere because it does not go with what is acceptable as norm now. That you have to own a big house, own fleet of big cars and these are negative influences and you cannot say you are a saint in a society where $90 \%$ of the people are corrupt". You definitely become a misfit in such situation, so you cannot say you are a saint..., you will do everything possible to exist, not minding".

Corruption breeds negative values and they often go together in corrupt societies. When public managers imbibe the corrupt values from the society, it negatively influences their official behaviours and activities. Such influence make public managers act corruptly in their official duties. Through such corrupt behaviours, they bring corruption into public organizations; this leads to ineffectiveness. In Nigeria, most interviewees confirm that corrupt values from the society manifest in public managers through unethical and unprofessional behaviours while performing their official duties. Such behaviours include demanding and receiving bribes, stealing public funds and resources, disregard for the organizations rules and regulations, during recruitments, lack of commitment to their jobs, bending organization's policies and rules, blackmailing others, witch-hunting perceived enemies, discriminatory behaviours, loss of integrity and transparency in organizational processes. It also corrupts managers' decision-making process and these make management of public organizations difficult and ineffective.

\section{Managers COMmunication BeHAVIOURS AND ORganizational EFFECTIVENESS}

Interviews conducted in Nigeria and Ghana show that corruption influences communication behaviours of public sector managers'. Due to the influence of corrupt values from the society, public sector managers arrogate onto themselves, a feeling of high social status and value. They make subordinates to "recognize" their social status and value, by creating status barriers that make it difficult for subordinates to gain direct access to them without following bureaucratic procedures. Such situation creates a distance that affects free flow of information between managers and employees. It kills employees' moral, motivation and reduces their commitment. This subsequently leads to ineffectiveness of public sector organizations. The result further show that public sector managers in both countries perform networking functions for their individual benefits than to achieve organizational goals. In Nigeria, they introduce manager/protégée relationships by creating a network of protégées (subordinates). The protégées enjoy managers' protection and get unmerited promotions and favour as rewards, and non-members of the network suffer discrimination. While the manager's control and power-base expands within the organization. This affects communication flow between managers and subordinates who are not members of the network. Status barrier and social distance inhibits horizontal communication, creates environment where respect and credibility goes to people based on their position, instead of quality of their inputs (Mosley Jr., Mosley Sr. \& Pietri 2011: 178).

In addition, this study discovered that corruption influence on public managers' quality of communication and communication method. For example in Nigeria, due to the presence of manager/protégée network, the content of information affects how it is transmitted to employees, and its recipients. Public sector managers communicate different information to different people in different ways, depending on the content of the information. Information relating to the network activities is passed to the members of the network, using a method peculiar to the network. This influences public managers' communication pattern and behaviours. Also, senior members (managers) of the network provide leadership to lower members within the organizational hierarchy through face-to-face verbal communication to avoid any trace of documentary evidence. In this way, public sector managers' communication behaviour affects effectiveness of public sector organizations. 
Even though communication shows higher relative contribution to both organizational and managers' effectiveness, this study discovered that majority of Ghanaian public sector managers perform less communication functions, and do not often communicate with their employees. However in Nigeria, the study reveals that although majority of public sector managers engage in communication functions, there is huge disconnection between managers and their employees because, instead of face-to-face communication which shows greater potential for organizational effectiveness, managers communicate with employees through correspondences, memos, text messages, and other paperwork. They only engage in face-to-face communication with their employees once in a month during staff meetings or during emergencies. They do not engage employees in routine face-to-face discussions to find out the challenges employees face and proffer immediate solution. In addition, communication behaviour of most public managers' affects employees' moral and motivation, and discourages employees from putting in their best to the organizations. Most managers treat employees with highhandedness, show insensitivity to employees' welfare, lack empathy, and do not notice employees' subtle communication resistance. They do not know when to be work centered and when to be human centered. While in Ghana, although majority of public managers perform less communication functions, when they do, they engage in face-to-face discussion with their employees, empathize with employees' when there is need, hold personal discussions with employees when they notice subtle communication resistance. These motivate employees to make extra effort to achieve organizational goals.

Public managers poor leadership behaviours manifest in different ways, including not keeping to their promises and agreements with employees, not leading by example, lack of transparency and not carrying employees along, lying and deceits, backbiting, intrigues, preferential treatments, stifling employees' rights and freedom, etc. These behaviours create a feeling of insecurity, unconducive work environment in employees and lack of understanding between managers' and their subordinates. This destroys team spirit and cause managers and employees to work on cross-purposes. These affect employees' performance and organizational effectiveness.

\section{Managers Networking BeHaViour and Organizational EFFECTIVENESS}

Through networking, managers build strong and valuable contacts within and outside their organizations. These contacts protect them and pave ways for their quick promotions ahead of their colleagues. In Nigeria, more than half of the interviewees agreed that their position as managers offer them opportunities to advance their career prospects. Similarly, in Ghana all the interviewees held the same view. They consider managerial positions as a springboard to achieve career success. Having got to the position of a manager, they get more involved in what will make their superiors and people outside the organizations like them and influence their promotions ahead of others. The quests for career progress make public managers to engage more in networking functions than communication activities. This makes them deviate from the organizational goals.

While networking in corrupt societies, interactions between public managers and people from outside their organizations directly or indirectly influence managers' official behaviours which expose them to unethical behaviours. This subsequently affects their effectiveness. However, nearly all the interviewees revealed that their interactions with people from outside their organizations influence them positively because the contributions, advise and criticisms they get from the people during their networking function help them to gain more knowledge, evaluate their performance, make corrections where necessary and improve on their performance. But, few interviewees from Nigeria were of the view that their interactions with people from outside their organizations influence them negatively because people from outside their organizations exert much pressure on them to involve in corrupt behaviours. Public managers' interactions with people outside their organizations provide opportunities for people to influence them positively or negatively.

\footnotetext{
"Usually, people come from various spheres of the society; they come with their own ideas. In some cases, you discover that they may have some ideas, which are better than what you had before but after discussing and interacting with them, you discover that their own ideas are superior to my ideas and which I always learn from such situation".
}

"When you talk about accountability, integrity and morality, people look at you like you come from the sky. People try to bribe you in the course of your job... They think you should be 
Effects of Corruption on Managers Communication and Networking Behaviours: Implications for Nigeria and Ghanaian Public Sector Effectiveness

corrupt and make more money, and they ask if you alone can sanitize this country and this affects us negatively in delivering our mandate here".

Political influence on public managers is one of the factors that influence managers' official behaviour in Nigeria and Ghana. Politicians allocate resources to, and head most public sector organizations in these countries. As part of public managers' jobs, they maintain close contacts with the politicians. Hence, it is difficult to avoid political influence, which affects networking behaviours and activities of public sector managers. Interviews from the two countries reveal that managers experience negative political influence and interferences during networking functions.

According to them, politicians interfere and influence management activities like recruitments and promotions, posting and transfer of employees, by pressurizing public managers to recruit, promote or transfer their candidates to better positions in their organizations. Other ways include tampering with budgetary allocations of public sector organizations, etc. This negatively influence the official behaviours of public managers who do not want to offend the politicians in order to keep their jobs; strengthen their positions in their organizations, get assurances of speedy promotions and more resource allocation to their organizations. Such behaviour affects the effectiveness of public sector organizations in these societies because merit and competence no longer matter; public managers no longer work to achieve organizational goals, rather to satisfy their political masters and their personal goals.

"So many things have influence over the management of this society... People sometimes come with letters from highly positioned people in the society and merit is not considered. Sometimes, when these highly placed people in the society come soliciting for one thing or the other, you have to wave so many things to appeal to them..., and if you do not do that, you will not succeed..."

"Yes, we get plenty of them. Political office holders often talk about their constituency and they do not support anything that does not favour them. For example, during budget defense, we have cases of them asking how many people you will give them, in terms of employment of those from their constituency. If you don't, they obstruct your presentation and distort the budget".

In these situations, public managers have no choice than to 'cooperate'. In some cases, refusal could lead to transfer, removal of such manager, or her/his organization will be starved of funds. These make public managers to collaborate with greedy politicians to carryout acts of corruption in public organizations. It makes the public to lose trust and confidence in public managers and public organizations. With such negative perception, it becomes difficult for the people to believe in public managers, or cooperate with public organizations for successful implementation of government programmes and policies.

Corruption diminishes the value system of a society. Those who corruptly enriched themselves are given high social value, recognition and respect due to their ill-gotten wealth. This leads to inordinate struggle among citizens to acquire wealth, which accords them high social value, respect and recognition. As members of the society, public managers also desire social value, respect and recognition that come through legitimate or illegitimate wealth. Such desire influences the networking behaviour of public managers in the two countries. Due to their positions in their organizations, members of the society believe that they have access to public funds; as a result, the people respect and give lots of honor and privileges to them. In return, the people expect them to reciprocate the honor, respect and privileges accorded to them. The situation puts pressure on public managers. Due to the pressure and desire to maintain the high status they enjoy in the society, some public managers compromise ethical standards and steal public funds to reciprocate the respect and privileges they enjoy. Such unethical behaviour affects effectiveness of public organizations in these countries.

"Competition for wealth within the environment affects behavior of managers in this organization because sometimes, managers are pushed to behave inappropriately. This reduces the level of revenue mobilization in this organization".

"...In a society where wealth and bogus status is accepted as a norm, heads of government agencies are bound to be negatively influenced and if they don't dance to the tune, their status 
Effects of Corruption on Managers Communication and Networking Behaviours: Implications for Nigeria and Ghanaian Public Sector Effectiveness

will be demeaned. For those young officers, all the talks about public service ethics and values are nowhere because it does not go with what is acceptable as norm now. That you have to own a big house, own fleet of big cars and these are negative influences and you cannot say you are a saint in a society where 90\% of the people are corrupt". You definitely become a misfit in such situation, so you cannot say you are a saint..., you will do everything possible to exist, not minding".

Corruption breeds negative values and they often go together in corrupt societies. When public managers imbibe the corrupt values from the society, it negatively influences their official behaviours and activities. Such influence make public managers act corruptly in their official duties. Through such corrupt behaviours, they bring corruption into public organizations; this leads to ineffectiveness. In Nigeria, most interviewees confirm that corrupt values from the society manifest in public managers through unethical and unprofessional behaviours while performing their official duties. Such behaviours include demanding and receiving bribes, stealing public funds and resources, disregard for the organizations rules and regulations, during recruitments, lack of commitment to their jobs, bending organization's policies and rules, blackmailing others, witch-hunting perceived enemies, discriminatory behaviours, loss of integrity and transparency in organizational processes. It also corrupts managers' decision-making process and these make management of public organizations difficult and ineffective.

\section{CONCLUSION AND FINDINGS}

This study discovered that corrupt values in the two countries influence the official behaviours and activities of public sector managers while performing communication and networking functions. Such influence significantly affects the effectiveness of public sector organizations in Nigeria and Ghana. Although networking sometimes affect public sector managers positively, in corrupt societies, networking functions make public managers vulnerable to unethical behaviour. Public managers often perform networking functions for their personal benefits and career progress; appropriate every good thing that comes from the organization to themselves (managers). Manager/protégée network relationship creates division that subsequently affects information flow among employees and managers of public sector organizations. In addition, political interferences make public managers to deviate from the goals of public sector organizations while performing networking functions. Even though communication functions show high relative contribution to effectiveness, face-to-face communication affects positively on employees' effectiveness than paper correspondences. Lack of communication between public sector managers and subordinates affects both horizontal and vertical flow of information.

In societies with high power distance culture and value system, public managers like other members of the society crave for, and attach high social status and value to themselves. They manifest bossy behaviours, create status barriers which limits horizontal flow of information between managers and subordinates, bully and intimidate employees, treat employees disrespectfully, show insensitivity and lack of understanding to employees' welfare, show no empathy and disregard for employees. In order to show off their 'authority and power', managers' exhibit intolerance and insensitivity to employees', and manifest inclination to punish employees' communication resistance with immediate disciplinary action without any formal discussion or attempt to talk things over.

"Such becomes insubordination. In fact, I cannot imagine such happening because of the consequences. You can only grumble and complain and you are not supposed to show it out..."

These poor leadership behaviours pose challenges to communication flow between managers and employees of public sector organizations. In order to improve the effectiveness of public organizations in the two countries, the governments should increase public education and value reorientation of the citizens, objectively enforce anti-corruption laws and introduce competitive salary system and compensation in public sector organizations. These will help promote discipline and ethical codes of public sector organizations.

\section{REFERENCES}

[1] Agranoff, Robert (2007). Managing Within Networks: Value to Public Organizations. Washington: George Town University Press. 
Effects of Corruption on Managers Communication and Networking Behaviours: Implications for Nigeria and Ghanaian Public Sector Effectiveness

[2] Berryman-Fink, Cynthia \& Fink Charles B. (1996). The Manager's Desk Reference. New York: American Management Association (AMACOM).

[3] Chalmers, Lesley Rachel (1991). Successful and Effective Managers - A Comparison between American Organizations and New Zealand Organization. Massey: Massey University New Zealand.

[4] Chaturvedi, P.D. \& Mukesh Chaturvedi (2006). Business Communication: Concepts, Cases and Applications. New Delhi: Dorling Kindersley Pvt. Ltd.

[5] Christiansen, Bryan \& Chandan Harish C. (2017). Handbook of Research on Human Factors in Contemporary Workforce Development. Pennsylvania: IGI Global.

[6] Chung-Ming, Lau, Ignace Ng \& Mee-Kau Nyaw (1997). The Effects of Managerial Activities on Managerial Success and Effectiveness. International Business Review 6: 4, 433-445.

[7] Danişman, Ş. Tosuntaş Ş.B. Karadă̆ E. (2015). The Effect of Leadership on Organizational Performance. In: Leadership and Organizational Outcomes Meta-Analysis of Empirical Studies, pp. 146-168. Karadağ E. ed. AG Switzerland: Springer, Cham.

[8] Denzin, Norman K. \& Yvonna S. Lincoln (2005). SAGE Handbook of Qualitative Research. 4th Edition. California: SAGE Publications Inc.

[9] Drucker, Peter F. (2011). People and Performance. Abingdon: Routledge.

[10] Edhlund, Bengt M. \& Allan G. McDougall (2016). NVivo 11 Essentials: Your Guide to the World's Most Powerful Data Analysis Software. Stallarholmen: Form \& Kunskap Ab.

[11] Friar, John H. \& Kimberly A. Eddleston (2007). Making Connections for Success: A Networking Exercise. Journal of Management Education 31: 1, 104-127.

[12] Grunig, Larissa A. Grunig James E. \& Dozier David M. (2002). Excellent Public Relations and Effective Organizations: A Study of Communication Management in Three Countries. London and New York: Routledge.

[13] Grunig James E. (1992). Communication, Public Relations, and Effective Organizations: An Overview of the Book. In: Excellence in Public Relations and Communication Management, pp. 1-36. Eds. Grunig, James E. Dozier David M. \& Grunig, Larissa A. New Jersey: Lawrence Erlbaum Associates, Ins., Publishers.

[14] Gudykunst, B. William \& Lee M. Carmen (2003). Cross-Cultural Communication Theories. In: CrossCultural and Intercultural Communication. Ed. Gudykunst, B. William. California: Sage Publications Inc.

[15] Hennink, Monique, Inge Hutter \& Ajay Bailey (2011). Qualitative Research Methods. London: SAGE Publications Ltd.

[16] Hofstede, Geert, Gert Jan Hofstede \& Micheal Minkov (2010). Cultures and Organizations Software of the Mind: Intercultural Cooperation and its Importance for Survival. New York: McGraw-Hill.

[17] Huczynski, Andrezej (2004). Influencing Within Organizations. 2nd Edition. New York: Routledge.

[18] Lashley, Conrad \& Lee-Ross Darren (2003). Organizational Behaviour for Leisure Services. Oxford: Butterworth-Heinemann.

[19] Loke, J. Chiok Foong (2001). Leadership behaviours: effects on job satisfaction, productivity and organizational commitment. Journal of Nursing Management, 9, pp. 191-204.

[20] Luthans, Fred Welsh Dianne B. H. \& Taylor III Lewis A. (1988).A Descriptive Model of Managerial Effectiven ess. Group and Organization Studies, Vol. 13, No. 2, pp. 148-162.

[21] Luthans, Fred Richard M. Hodgetts \& Stuart Rosencrantz (1988). Real Managers. Massachusetts: Ballinger Publishing Company.

[22] Meier, Kenneth J. \& Laurence J. O’Toole Jr. (2010a). Beware of Managers not Bringing Gifts: How Managerial Capacity Augments the Impact of Managerial Networking. Public Administration 88: 4, 10251044.

[23] Meier, Kenneth J. \& Laurence J. O’Toole Jr. (2010c). Managerial Network, Managing the Environment, and Programme Performance: A Summary of Findings and an Agenda. In: Public Management and Performance Research Directions 127-151. Eds. Walker, Richard M. Boyne George A. \& Brewer Gene A. Cambridge: Cambridge University Press.

[24] Mintzberg, Henry (1980). The Nature of Managerial Work. New Jersey: Prentice-Hall, Inc. (Original version 1973).

[25] Mosley Jr., Donald C. Donald C. Mosley Sr., \& Paul H. Pietri (2011). Supervising Management: The Art of Inspiring, Empowering and Developing People. Ohio: South Western Cengage Learning.

[26] Mullins, Laurie J. (2007). Management and Organizational Behaviour, Eight Edition. Essex: Pearson Education Limited. 
Effects of Corruption on Managers Communication and Networking Behaviours: Implications for Nigeria and Ghanaian Public Sector Effectiveness

[27] Nwokorie, Ethelbert Chinedu (2017). Challenges to Effective Management of Public Sector Organizations in an Institutionally Corrupt Society: A Study of Nigeria. Doctoral Thesis, Vaasa: University of Vaasa.

[28] O’Driscoll, Michael P. Humphries Maria \& Larsen Henrik H. (1991). Managerial Activities, Competence and Effectiveness: Manager and Subordinate Perceptions. The International Journal of Human Resource Management, Vol.12, Issue 3, pp. 313-326.

[29] Parkin, James (1996). Management Decisions for Engineers. London: Thomson Telford Publishing.

[30] Pepermans, Roland Cindy Mentens Maarten Goedee Marc Jegers \& Kristof Van Roy (2001). Differences in Managerial Behaviour between Head Nurses and Medical Directors in Intensive Care Units in Europe. International Journal of Health Planning and Management, 16, pp. 281-295.

[31] Picardi, Richards (2001). Skills of Workplace Communication: A Hanbbook for T \& D Specialists and their Organizations. Connecticut: Greenwood Publishing Group, Inc.

[32] Riggio, Ronald E. (2016), Introduction to Industrial/Organizational Psychology, sixth Edition. New York: Routledge.

[33] Robbins, P. Stephen (2009). Organizational Behavior: Global and South African Perspectives. Cape Town: Pearson Education Inc.

[34] Schermerhorn, R. John (2011). Exploring Management. New Jersey: John Willey \& Sons Inc.

[35] Srivastava, Nivedita \& Shreekumar K. Nair (2011). Androgyny and Rational Emotive Behaviour as Antecedents of Managerial Effectiveness. Vision 15: 4, 303-314.

[36] Su, Zhongfeng, Xie En \& Wang Dong (2015). Entrepreneurial Orientation, Managerial Networking, and New Venture Performance in China. Journal of Small Business Management 53: 1, 228- 248.

[37] Tweedy, James T. (2014). Healthcare Hazard Control and Safety Management. Third Edition. Boca Raton: Taylor \& Francis Group.

[38] Van Der Velge, Manady E. G. Jansen Paul G.W. \& Vinkenburg Claartje J. (1999). Managerial Activities among Top and Middle Managers: Self versus other Perceptions. Journal of Applied Management Studies, Vol. 8, No. 2, pp. 161-174.

[39] Walela, Kisiangani \& Okwemba Emily Mokeira (2015). Effect of Leadership Behavior on the Performance of Micro-Financial Institutions in Kakamega County. International Journal of Scientific and Technology Research, 4(2), pp. 239-252.

[40] Young, M. \& Post J.E. (1993). Managing to Communicate, Communicating to Manage: How Leading Companies Communicate with Employees. Organizational Dynamics, 22: 1, 31-44.

[41] Yukl, Gary (2012). Effective Leadership Behaviour: What we know and what Questions need more Attention. Academy of Management Perspectives, Vol. 26, No. 4, 66-85. doi:10.5465/amp.2012.0088.

[42] Zelter, Christine-Diana (2011). Organizational Communication - A Premise for Organizational Efficiency and Effectiveness (Doctoral dissertation). Cluj-Napoca: University of Babes-Bolyai.

Citation: Ethelbert Chinedu Nwokorie. "Effects of Corruption on Managers Communication and Networking Behaviours: Implications for Nigeria and Ghanaian Public Sector Effectiveness". International Journal of Managerial Studies and Research (IJMSR), vol 6, no. 11, 2018, pp. 51-63. doi: http://dx.doi.org/10.20431/2349-0349.0611006.

Copyright: (C) 2018 Authors. This is an open-access article distributed under the terms of the Creative Commons Attribution License, which permits unrestricted use, distribution, and reproduction in any medium, provided the original author and source are credited. 